\title{
ANALISIS KESALAHAN MORFOLOGI DALAM PENULISAN MAKALAH MAHASISWA HUKUM EKONOMI SYARIAH IAIN SURAKARTA
}

\author{
Bahaudin Alfiansyah Syafi'i ${ }^{1}$, Ira Khoirun Niha $^{2}$, Silfiyatun Nisaa ${ }^{3}$ \\ 1,2,3 Institut Agama Islam Negeri Surakarta, Indonesia
}

DOI: 10.23917/humaniora.v22i1.8153

Submit: 20 Mei 2019. Revisi: 15 Juli 2020. Diterima: 1 Januari 2021.

Available Online: 27 Januari 2021. Periode Terbit: Februari 2021.

\begin{tabular}{l}
\hline Kaywords \\
\hline language errors in \\
morphology, \\
student papers, \\
type of language \\
error \\
\\
\hline Corresponding \\
Author \\
\hline Nama \\
Afiliasi \\
Negara \\
Email: \\
Telp: (disarankan \\
menggunakan \\
nomor Whatsapp)
\end{tabular}

Abstract

This research aims to find the forms of language errors in the making of papers by students of Islamic Economics Law (HES), in particular class D in the semester VI of the 2019 academic year at the State Islamic Institute of Surakarta. To reach this goal, we employ a combination of descriptive and qualitative methods. We focused on the written errors in the linguistic field of morphology. The data were obtained through the note-taking method. They were then analysed was by making groups of the data, proceed with a presentation of the data, and verification of the data. The results of the study show 13 kinds of errors in the field of morphology. They are the writing the prefix di-that should be merged into non-merging and vice versa, the writing of the prefix ber-, the writing of prefix me-, the writing of the prefix ter-, the use of suffix-nya, the use of suffix-kan, the combination of the prefix di-with suffix-kan, the writing of prefix me-in combination with suffix -i, the use of prepositions, the writing of the simulphic me-kan, the use of confix ke-an, and the writing of confix peran. These results indicate that students must continue to learn the rules in scientific writing that refer to the General Indonesian Spelling Guidelines (PUEBI).

\begin{tabular}{ll}
\hline Kata Kunci & Abstrak \\
\hline jenis kesalahan & Penelitian ini bertujuan mengetahui bentuk kesalahan bahasa pada \\
bahasa, & mahasiswa Hukum Ekonomi Islam (HES) semester VI tahun 2019 di Institut \\
kesalahan & Agama Islam Negeri Surakarta. Penelitian ini menggunakan metode \\
penulisan bahasa & kualitatif deskriptif. Fokus penelitian pada kesalahan bahasa tertulis di \\
dalam bidang & bidang morfologi. Data diperoleh melalui teknik catat. Analisis data \\
morfologi, & dilakukan dengan mengelompokkan data yang diperoleh kemudian \\
makalah siswa & dilanjutkan dengan penyajian data dan verifikasi. Hasil penelitian \\
& menemukan tiga belas jenis kesalahan bahasa bidang morfologi pada \\
& makalah siswa HES semester VI di IAIN Surakarta, yaitu: penulisan \\
& awalan di- yang harus digabung menjadi non-merging dan sebaliknya, \\
& penulisan prefiks ber-, penulisan prefiks-, penulisan prefiks ter-, \\
& penggunaan sufiks -nya, penggunaan sufiks -kan, penulisan prefiks \\
& gabungan di- dengan sufiks -kan, penulisan prefiks me-kombinasi dengan \\
& sufiks -i, penulisan preposisi, penulisan simulfiks me-kan, penggunaan \\
& konfiks ke-an, dan penulisan konfiks per-an. Hasil tersebut menunjukan \\
& bahwa siswa harus terus mempelajari kaidah-kaidah dalam penulisan \\
& ilmiah yang mengacu pada Pedoman Umum Ejaan Bahasa Indonesia \\
& (PUEBI).
\end{tabular}




\section{PENDAHULUAN}

Seseorang yang akan memulai proses pembuatan karya tulis harus mempunyai keterampilan menulis yang baik. Keterampilan menulis diperlukan untuk kegiatan berkomunikasi dengan pihak lain menggunakan bahasa tulis sebagai media (Dalman, 2014: 3). Keterampilan menulis diperlukan untuk memberikan informasi kepada pembaca dalam memahami maksud dan tujuan penulis membuat suatu karangan (Gie, 2002: 3). Keterampilan dalam menulis harus diterapkan secara berjenjang dan terstruktur pada seluruh jenjang akademisi guna mencapai kemampuan menulis yang baik. Akan tetapi, seseorang dapat mempunyai keterampilan menulis jika melakukan kegiatan menulis secara rutin dengan membaca berbagai bahan bacaan. Dengan demikian, tidak menutup kemungkinan seseorang yang tidak terlibat dalam lingkup akademisi dapat mempunyai keterampilan menulis yang baik.

Pendidikan keterampilan menulis dimaksudkan supaya pelaku akademisi dapat menerapkan kaidah kebahasaan yang baik dan benar dalam menulis karya. Salah satu karya tulis yang memperhatikan kaidah kebahasaan yaitu makalah. Hal tersebut berdasarkan pengertian makalah merupakan karya tulis yang mengandung unsur kekinian, ditulis secara sistematis dan bersifat ilmiah (Tanjung \& Ardial, 2010: 7). Berkaitan dengan hal tersebut pembuatan makalah harus dilakukan sesuai Pedoman Umum Ejaan Bahasa Indonesia (PUEBI). Hal ini disebabkan PUEBI merupakan acuan dalam penulisan yang baik dan benar. Selain itu, penulisan yang baik dan benar bertujuan supaya tidak terjadi penerimaan informasi yang salah dari pembaca tulisan.

Pemahaman mengenai cara menulis yang baik dan benar dapat ditingkatkan dengan minat baca seseorang yang harus tinggi. Akan tetapi, di era digitalisasi seperti saat ini informasi yang berkembang di masyarakat berjalan dengan cepat tanpa melewati proses penyaringan konten bahasa yang baik dan benar. Oleh karena itu, menuntut pembaca harus selektif dalam membaca informasi yang berkembang di dunia maya untuk mengetahui penulisan yang baik dan benar baik karya tulis ilmiah maupun nonilmiah. Hal itu supaya tidak akan terjadi pengulangan penulisan yang salah. Selain itu tidak dipungkiri dibandingkan dengan bahasa lisan, bahasa tulis mempunyai perbedaan penerapan yang signifikan. Slavin(2011: 21) menyampaikan bahwa bahasa lisan tidak hanya mengharuskan untuk mempelajari kata-kata, tetapi juga mempelajari aturan pembentukan kata dan kalimat. Bahasa lisan dapat disampaikan dengan penggunaan intonasi sesuai konteks ucapan maupun melibatkan gesture atau gerak tubuh supaya mitra tutur memahami maksud perkataan dengan baik, sedangkan bahasa tulis harus memperhatikan berbagai aspek dari segi kesopanan, ejaan, hingga tujuan tulisan dibuat.

Seperti yang dijelaskan oleh (Badudu, 1985: 6) bahwa bahasa lisan merupakan bahasa yang lebih bebas penggunaannya karena terdapat faktor situasi sebagai pendukung bahasa yang dituturkan oleh penutur, sedangkan dalam bahasa 
tulis penjelasan tentang maksud bahasa dan situasi harus dinyatakan dengan kalimat. Perbedaan tersebut yang menjadikan sering terjadinya kesalahan penulisan pada karya tulis ilmiah akibat penguasaan bahasa tulis dengan bahasa lisan yang tidak seimbang. Hal ini juga berdampak pada mahasiswa yang sering kali merasa kebingungan ketika akan melakukan keterampilan menulis. Fajriyani, dkk (2020) menyatakan bahwa kesalahan berbahasa adalah suatu penggunan bahasa yang tidak sesuai dengan kaidah bahasa Indonesia, baik lisan atau tulis, sedangkan analisis kesalahan berbahasa adalah suatu kegiatan yang mengkritik, memperbaiki, dan mengumpulkan suatu data kesalahan berbahasa dan mengklasifikasikannya sesuai bidangnya Analisis kesalahan berbahasa memiliki orientasi yang dilihat bidang lingustik, yang berkaitan dengan semantik, morfologi, leksikal, dan fonologi.

Berkaitan dengan kesalahan berbahasa dalam penulisan, salah satu kesalahan yang terjadi yaitu kesalahan bidang morfologi. Padahal peran morfologi sangat penting sebagai pembentukan morfem yang mencakup kata maupun bagianbagian kata (Rohmadi,dkk., 2012: 3). Berdasarkan hal tersebut dapat diambil contoh jika suatu makalah tidak memperhatikan aspek linguistik salah satunya bidang morfologi dalam penulisannya, makalah yang dihasilkan akan terdapat penulisan kata atau kalimat yang kurang tepat. Hal tersebut bisa saja berkaitan dengan tingkat penguasaan keterampilan menulis mahasiswa maupun proses pemberian materi tentang penulisan yang baik dan benar dari dosen kurang maksimal.

Penelitian yang relevan pernah dilakukan oleh (Nurwicaksono \& Diah, 2018) dengan judul "Analisis Kesalahan Berbahasa Indonesia pada Teks Ilmiah Mahasiswa". Hasil dalam analisis tersebut ditemukan adanya kesalahan berbahasa berdasarkan error, mistake, dan lapses sehingga ditemukan alasan mengapa terjadi kesalahan berbahasa. Meninjau dari penelitian tersebut penelitian ini juga menganalisis kesalahan berbahasa namun lebih tertuju pada kesalahan berbahasa bidang morfologi sehingga diharapkan adanya penelitian ini menunjukkan tingkat pemahaman penulisan yang baik dan benar oleh subjek penelitian dapat diketahui dengan jelas. Selain itu, juga menjadi gambaran adanya faktor lain dalam kesalahan berbahasa selain error, mistake, dan lapses. Pemahaman mengenai penulisan yang baik sangat berpengaruh untuk penerimaan informasi secara baik dari penulis dan pembaca yang tersampaikan sesuai dengan keinganan penulis (Nurgiyantoro, 2010: 425) sehingga seorang mahasiswa sebagai pelaku akademisi sudah seharusnya memahami dengan detail pembuatan karya tulis ilmiah.

Selain itu, penelitian relevan lain dari (Priyono, 2012) berjudul "Analisis Kesalahan Berbahasa Bidang Morfologi pada Mading di Universitas Muhammadiyah Surakarta”. Penelitian Priyono dengan penelitian ini mempunyai persamaan analisis kesalahan berbahasa bidang morfologi, akan tetapi terdapat perbedaan pada sumber data yang diambil. Pada jurnal ilmiah tersebut Priyono menjelaskan bahwa banyak kesalahan berbahasa pada mading akibat pembuat 
mading kurang memperhatikan penggunaan ejaan. Selain itu diperoleh alasan karena pembuatan tulisan mading masih belum berpedoman pada kaidah penulisan yang baik dan benar. Meskipun mading dan makalah memiliki pengertian yang berbeda, akan tetapi dalam menyampaikan suatu tulisan kepada khalayak luas sudah seharusnya memperhatikan kaidah kebahasaan. Tujuannya adalah supaya khalayak atau pembaca memahami maksud tulisan dengan jelas.

Terdapat penelitian lain dari (Reistanti, 2017) menulis jurnal "Analisis Kesalahan Berbahasa pada Penulisan Cerita Fabel oleh Siswa Kelas VIII E di SMP 2 Muhammadiyah Surakarta". Tujuan penelitian tersebut untuk mendeskripsikan pembuatan cerita fabel oleh siswa yang masih terjadi kesalahan berbahasa. Adapun yang menjadi data yaitu aspek-aspek dalam kesalahan berbahasa seperti kesalahan pada fonologi, morfologi, dan sintaksis. Senada dengan Reistanti, (Santoso \& Sabardila, 2019) menganalisis dari berbagai aspek, dengan judul penelitian Analisis Kesalahan Berbahasa Pidato Mahasiswa Magister Pengkajian Bahasa Universitas Muhammadiyah Surakarta yang Memerankan Diri Menjadi Calon Kepala Daerah Kabupaten Blora. Dari aspek bidang kesalahan morfologi, terdapat kesalahan yang meliputi penulisan kata depan, penulisan kata ulang, bentuk pleonasme, dan penulisan gabungan prefik meN- dengan -kan,(Santoso \& Sabardila, 2019).

Berdasarkan jurnal tersebut terdapat kesamaan penelitian dengan penelitian ini yaitu sama-sama menganalisis kesalahan berbahasa bidang morfologi. Akan tetapi, penelitian Reistanti lebih kepada keseluruhan aspek kesalahan berbahasa sedang penelitian ini lebih fokus pada kesalahan berbahasa bidang morfologi sehingga dapat diketahui bahwa pemahaman penulisan dalam bidang morfologi memang mempunyai peran penting dalam pembuatan karya tulis, selain pemahaman aspek linguistik yang lain.

Jurnal yang berjudul "Analisis Kesalahan Morfologi Bahasa Indonesia dalam Surat Kabar Radar Majalengka Edisi 16 dan 25 April 2016" yang ditulis oleh (Sutrisna, 2017) juga menjadi penelitian yang relevan. Penelitian tersebut mendeskripsikan kesalahan berbahasa dalam segi kata, bentuk kata, dan pembentulannya sehingga diketahui secara umum kesalahan berbahasa seperti pada sufiks, prefiks, konfiks, penggunaan kata. Kaitannya dengan penelitian ini yaitu sama-sama menganalisis kesalahan dalam morfologi. Selain itu, juga digunakan metode simak catat sebagai pengumpulan data. Akan tetapi, perbedaan terletak pada sumber data yang digunakan. Penelitian Sutrisna lebih mengarah pada lingkup bahasa tulis yang dibawakan oleh lingkup jurnalistik, sedangkan penelitian ini menggunakan sumber makalah mahasiswa sebagai sumber data. Hal ini berkaitan pada ranah perkembangan keterampilan lingkup akademisi untuk megetahui tingkat keterampilan dalam menulis yang dilakukan oleh mahasiswa sebab mahasiswa sudah seharusnya mengetahui aturan dalam penulisan yang baik.

Penelitian (Ariningsih, Sumarwati, \& Kundharu, 2012) berjudul "Analisis Kesalahan Berbahasa Indonesia dalam Karangan Eksposisi Siswa Sekolah 
Menengah Atas". Terdapat kesamaan dalam penelitian mengenai analisis kesalahan berbahasa. Akan tetapi terdapat perbedaan dengan penelitian ini pada ranah analisis. Penelitian Ariningsih meneliti aspek kesalahan ejaan, kesalahan diksi, kesalahan kalimat, dan kesalahan paragraf sehingga Ariningsih dapat mengetahui bahwa kesalahan berbahasa pada siswa terjadi akibat kurangnya penguasaan kaidah kebahasaan. Adapun penelitian ini lebih tertuju pada kesalahan berbahasa bidang morfologi. Berdasarkan hal tersebut terdapat perbedaan penelitian ini dengan penelitian Ariningsih. Penelitian ini lebih difokuskan pada bidang morfologi.

Sumber data berupa makalah mahasiswa jurusan Hukum Ekonomi Syariah (HES). Hal itu dikarenakan mahasiswa HES bukan merupakan mahasiswa bahasa sehingga sangat relevan untuk mengetahui tingkat keterampilan menulis mahasiswa yang bukan jurusan bahasa. Meskipun mahasiswa sudah mengetahui pentingnya pembuatan makalah yang baik dan benar, akan tetapi masih sering terdapat kesalahan berbahasa yang dilakukan oleh mahasiswa. Adanya kesalahan kecil jika tidak diperbaiki akan menimbulkan kesalahan-kesalahan besar. Hal itulah yang mendasari pemikiran peneliti untuk mendata kesalahan bidang morfologi yang ada pada makalah jurusan Hukum Ekonomi Syariah semester VI Institut Agama Islam Negeri Surakarta tahun 2019.

\section{METODE}

Subjek penelitian ini adalah mahasiswa Jurusan Hukum Ekonomi Syariah kelas D semester VI Institut Agama Islam Negeri Surakarta tahun 2019. Data pada penelitian ini bersumber dari kumpulan tugas pembuatan makalah beberapa mata kuliah yang diperoleh mahasiswa Jurusan Hukum Ekonomi Syariah kelas D semester VI Institut Agama Islam Negeri Surakarta tahun 2019. Sumber data yang diperoleh sejumlah 23 makalah. Adapun perincian dari 23 makalah yang bersumber dari beberapa mata kuliah, sebagai berikut; Hukum Perkawinan (1), Sosiologi Hukum (1), Fikih Munakahat (1), Ulumul Hadist (2), Sejarah Perkembangan Hukum Islam (7), Sejarah Peradaban Islam (1), Asuransi Syariah (3), Kaidah Ushulliyah dan Fiqhiyah (2), Peradilan Agama di Indonesia (1), Hukum Perikatan Islam di Indonesia (1), dan Tafsir Ayat-Ayat Hukum Ekonomi Syariah (2). Data yang digunakan berupa seluruh isi makalah yang ditulis oleh mahasiswa. Selanjutnya, data dianalisis berdasarkan kesalahan berbahasa bidang morfologi.

Teknik pengumpulan data menggunakan metode simak catat. Menurut (Mahsun, 2005: 90) teknik simak dilakukan dengan cara melakukan penyimakan untuk memperoleh data. Begitu pula Sudaryanto(2015: 203) mengatakan bahwa metode simak adalah metode yang digunakan dalam penelitian bahasa dengan cara menyimak penggunaan bahasa pada objek yang akan diteliti. Penyediaan data yang dilakukan dengan cara membaca secara seksama seluruh tulisan makalah yang menjadi sumber data dengan memperhatikan kesalahan bidang morfologi. 
Selanjutnya dilakukan pencatatan sesuai dengan data yang diperlukan untuk tujuan penelitian. Selanjutnya, mengelompokkan data sesuai dengan kebutuhan untuk mencari simpulan (Subroto, 1992: 41-42). Langkah selanjutnya analisis data yang bertujuan untuk mengetahui seberapa banyak kesalahan berbahasa dalam bidang morfologi dengan diberikan langkah pembenaran. Penting bagi peneliti untuk menelaah data secara cermat dan melakukan pengelompokan data. Apabila data sudah diperoleh, langkah terakhir melakukan penarikan simpulan hingga ditemukan hasil pelelitian untuk mengetahui tingkat kesalahan berbahasa pada makalah.

Langkah-langkah dalam penelitian untuk menganalisis data sebagai berikut: (a) mengumpulkan data-data berupa tugas makalah mahasiswa HES kelas D semester VI angkatan 2016, (b) memilah kata atau kalimat yang mengandung unsur kesalahan berbahasa berupa kesalahan bidang morfologi, (c) menjabarkan temuan data untuk dianalisis, dan (d) melakukan penarikan simpulan dari data yang telah dirumuskan.

\section{HASIL}

Penelitian ini dilakukan dengan cara menganalisis data dengan mengelompokkan sesuai dengan jenis kata yang terbukti sebagai wujud dari kesalahan dalam berbahasa pada bidang morfologi. Selanjutnya, hasil temuan kesalahan ditulis dengan kata yang bercetak miring. Kesalahan afiksasi terjadi karena adanya penambahan prefiks (awalan), infiks (sisipan), sufiks (akhiran), atau simulfiks (mengganti fonem), konfiks (awalan dan akhiran) (Markhamah \& Sabardila, 2011: 124). Ditemukan kesalahan dalam penulisan prefiks terdapat sepuluh kesalahan, penulisan sufiks empat kesalahan, gabungan prefiks dengan sufiks dua kesalahan, penulisan kata depan terdapat dua kesalahan, simulfiks ditemukan satu kesalahan, dan konfiks ke-an ditemukan dua kesalahan.

Banyaknya kesalahan berbahasa dalam karya tulis makalah mahasiswa disebabkan masih kurang maksimal mahasiswa dalam menerapkan penulisan yang baik dan benar. Selain itu, mahasiswa masih mengesampingkan tingkat keterampilan menulis yang harus cermat.

Berikut hasil temuan kesalahan morfologi tersebut beserta analisis perbaikan data temuan kesalahan morfologi dalam makalah mahasiswa Hukum Ekonomi Syariah IAIN Surakarta.

\section{Kesalahan Dalam Penulisan Prefiks Di- Yang Seharusnya Digabung} Tetapi Dipisah

Wujud Dalam Kalimat:

a. "Pengadilan Agama Di Pimpin Oleh Seorang Ketua Dan Dibantu Oleh Seorang Wakil Ketua."

Analisis Terhadap Kesalahan:

Afiks Di- Pada Kata Di Pimpin Dalam Kalimat Di Atas Seharusnya Ditulis Serangkai Dengan Kata Dasar Yang Mengikutinya. Hal Ini 
Dikarenakan Sukukata $D i$ Pada Kalimat Di Atas Berfungsi Sebagai Awalan Dan Tidak Menunjukkan Kata Tempat.

Di + Pim + Pin $=$ Dipimpin

Perbaikan Dari Kalimat Di Atas Sebagai Berikut:

"Pengadilan Agama Dipimpin Oleh Seorang Ketua Dan Dibantu Oleh Seorang Wakil Ketua."

b. "Kedudukan Nabi Muhammad Sebagai Utusan Tuhan Tidak Mungkin Di Ganti.

Analisis Terhadap Kesalahan"

Afiks Di- Pada Kata Di Ganti Dalam Kalimat Di Atas Seharusnya Ditulis Serangkai Dengan Kata Dasar Yang Mengikutinya. Hal Ini Dikarenakan Sukukata $D i$ Pada Kalimat Di Atas Berfungsi Sebagai Awalan, Dan Tidak Menunjukkan Kata Tempat.

$D i+G a n+T i=$ Diganti

Perbaikan Dari Kalimat Di Atas Sebagai Berikut:

Kedudukan Nabi Muhammad Sebagai Utusan Tuhan Tidak Mungkin Diganti.

c. "Sesudah Di Pilih, Khalifah Berjanji Bahwa Ia Akan Memenuhi Kewajiban Yang Dipercayakan Kepadanya".

Analisis Terhadap Kesalahan:

Afiks Di- Pada Kata Di Pilih Dalam Kalimat Di Atas Seharusnya Ditulis Serangkai Dengan Kata Dasar Yang Mengikutinya. Hal Ini Dikarenakan Sukukata $D i$ Pada Kalimat Di Atas Berfungsi Sebagai Awalan Dan Tidak Menunjukkan Kata Tempat.

$\mathrm{Di}+\mathrm{Pi}+\mathrm{Lih}=$ Dipilih

Perbaikan Dari Kalimat Di Atas Sebagai Berikut:

"Sesudah Dipilih, Khalifah Berjanji Bahwa Ia Akan Memenuhi Kewajiban Yang Dipercayakan Kepadanya".

d. "Abu Bakar Pun Mengikuti Seluruh Peperangan Yang Di Ikuti Rasulullah SAW."

Analisis Terhadap Kesalahan

Afiks Di- Pada Kata Di Ikuti Dalam Kalimat Di Atas Seharusnya Ditulis Serangkai Dengan Kata Dasar Yang Mengikutinya. Hal Ini Dikarenakan Sukukata Di- Pada Kalimat Di Atas Berfungsi Sebagai Awalan, Dan Tidak Menunjukkan Kata Tempat.

Di $+I k u t+I=$ Diikuti

Perbaikan Dari Kalimat Di Atas Sebagai Berikut:

"Abu Bakar Pun Mengikuti Seluruh Peperangan Yang Diikuti Rasulullah SAW". 


\section{Kesalahan dalam Penulisan Kata Depan di- yang Seharusnya Dipisah tetapi Digabung}

Wujud dalam kalimat:

a. "Dan sebagai Khalifah Tuhan dibumi ini."

Analisis terhadap kesalahan

Kata di pada frasa depan dibumi dalam kalimat di atas seharusnya ditulis terpisah dengan kata dasar yang mengikutinya. Hal ini dikarenakan suku kata $d i$ - pada kalimat di atas berfungsi untuk menunjukkan tempat. $d i+b u m i=d i$ bumi

Perbaikan dari kalimat di atas sebagai berikut:

"Dan sebagai khalifah Tuhan di bumi ini."

b. “... dalam perjalanan hijrah hingga sampai dikota Madinah. “" Analisis terhadap kesalahan

Kata di pada frasa depan dikota dalam kalimat di atas seharusnya ditulis terpisah dengan kata dasar yang mengikutinya. Hal ini dikarenakan suku kata $d i$ - pada kalimat di atas berfungsi untuk menunjukkan tempat. $d i+k o t a=d i$ kota

Perbaikan dari kalimat di atas sebagai berikut:

"... dalam perjalanan hijrah hingga sampai di kota Madinah."

c. ... seorang penggembala kambing sedang menggiring kambingnya ke arah teduhan dibawah batu tersebut ...

Analisis terhadap kesalahan

Kata depan di pada frasa depan dibawah dalam kalimat di atas seharusnya ditulis terpisah dengan kata dasar yang mengikutinya. Hal ini dikarenakan di pada kalimat di atas berfungsi untuk menunjukkan tempat. $d i+b a+w a h=d i b a w a h$

Perbaikan dari kalimat di atas sebagai berikut:

“... seorang penggembala kambing sedang menggiring kambingnya ke arah teduhan di bawah batu tersebut ...".

\section{Kesalahan Penulisan Prefiks ber-}

Wujud dalam kalimat

Orang yang transaksi haruslah berakal sehat, bukan orang gila, terganggu akalnya ataupun kurang akalnya.

Analisis terhadap kesalahan 
Kata transaksi pada kalimat di atas tidak baku sehingga perlu penambahan prefiks ber- yang ditulis sebelum kata dasarnya.

Ber + transaksi $=$ bertransaksi

Perbaikan dari kalimat di atas sebagai berikut:

Orang yang bertransaksi haruslah berakal sehat, bukan orang gila, terganggu akalnya ataupun kurang akalnya.

\section{Kesalahan Penulisan Prefiks me-}

Wujud kesalahan kalimat

Komentar secara dalam tentang tafsir Al-quran, fiqh para imam mujtahid dan karangan-karangannya dalam ilmu ushul fiqh.

Analisis terhadap kesalahan

Penulisan dalam pada data di atas tidak sesuai dengan kaidah bahasa Indonesia. Kata dalam pada kalimat di atas menjadi tidak baku dan kurang tepat dalam penggunaannya. Oleh karena itu, prefiks me- dapat ditambahkan ditulis di depan kata dasar yang mengikutinya.

$m e+$ dalam $=$ mendalam

Perbaikan dari kalimat di atas sebagai berikut:

Komentar secara mendalam tentang tafsir Al-quran, fiqh para imam mujtahid dan karangan-karangannya dalam ilmu ushul fiqh.

\section{Kesalahan Penulisan Prefiks ter-}

Wujud kesalahan

Sedangkan secara etimologi dapat beberapa definisi yang diberikan.

Analisis terhadap kesalahan

Istilah konfiks ke-an yang mengarahkan pada suatu hal atau keadaan dibentuk dari pangkal yang berupa bentuk dasar atau bentuk yang berprefiks ber-, ter-, dan se-. ter + dapat $=$ terdapat

Perbaikan terhadap kalimat diatas sebagai berikut:

Adapun secara etimologi terdapat beberapa definisi yang diberikan.

\section{Kesalahan dalam Pemakaian Sufiks -nya}

Wujud dalam kalimat:

a. Asuransi Islam tumbuh dan berkembang seiring dengan tumbuh dan berkembang perbankan syariah.

Analisis terhadap kesalahan 
Bentuk sufiks - nya dalam kalimat di atas menjelaskan situasi sehingga ditulis menempel pada bagian belakang dari bentuk kata dasar yang diikutinya. Kata berkembang merujuk pada kata berkembang sebelumnya sehingga harus diikuti sufiks -nya.

berkembang + nya $=$ berkembangnya

Perbaikan dari kalimat di atas sebagai berikut:

Asuransi Islam tumbuh dan berkembang seiring dengan tumbuh dan berkembangnya perbankan syariah.

b. Tindakan untuk mengantisipasi terjadi konflik sebelum melakukan perkawinan.

Analisis Kesalahan

Kata terjadi pada kalimat di atas kurang tepat sehingga perlu penambahan sufiks - nya agar melekat pada kata dasarnya.

terjadi + nya $=$ terjadinya

Perbaikan dari kalimat di atas sebagai berikut:

Tindakan untuk mengantisipasi terjadinya konflik sebelum melakukan perkawinan.

\section{Kesalahan dalam Pemakaian Sufiks -kan}

Wujud dalam kalimat:

a. Hal ini memerlukan suatu informasi yang komprehensif untuk memberi pemahaman kepada khalayak umum agar tidak terdapat pemahaman yang keliru atas asuransi Islam.

Analisis terhadap kesalahan

Kata memberi pada kalimat di atas kurang baku sehingga perlu tambahan sufiks - kan yang ditulis mengikuti kata dasarnya agar kalimat tersebut menjadi baku.

memberi+kan $=$ memberikan

Perbaikan dari kalimat di atas sebagai berikut:

Hal ini membutuhkan suatu informasi yang komprehensif untuk memberikan pemahaman kepada khalayak umum agar tidak terdapat pemahaman yang keliru atas asuransi Islam.

b. Perjanjian perkawinan merupakan istilah yang diambilkan dari judul.

Kata diambilkan pada kalimat di atas tidak sesuai sebab tidak baku. Sufiks - kan pada kata diambilkan dapat dihilangkan sehingga menjadi diambil. $d i+a m b i l=$ diambil 
Perbaikan dari kalimat di atas sebagai berikut:

Perjanjian perkawinan merupakan istilah yang diambil dari judul.

\section{Kesalahan Penulisan Gabungan Prefiks di- dengan Sufiks -kan}

Wujud dalam kalimat

Akad yang tidak dapat batal, yaitu 'aqduzziwaj.

Analisis terhadap kesalahan

Kata batal pada kalimat di atas kurang baku sehingga perlu penambahan prefiks $d i$ - dan sufiks - kan yang ditulis dengan kata dasarnya.

di+batal $=$ dibatal

dibatal $+k a n=$ dibatalkan

Perbaikan dari kalimat di atas sebagai berikut:

Akad yang tidak dapat dibatalkan, yaitu 'aqduzziwaj.

\section{Kesalahan Penulisan Gabungan dari Prefiks me- dengan Sufiks - $i$}

Wujud kesalahan

Karena kita perlu siasat agar bisa mengetahui perkembangan-perkembangan setiap zamannya.

Analisis terhadap kesalahan:

Bentuk kata dasar yang berfonem awal $\mathrm{k}, \mathrm{p}, \mathrm{t}$, dan $\mathrm{s}$ akan luluh jika mendapatkan prefiks me-. Seperti kesalahan pada penulisan bentuk kata dasar siasat yang berfonem awal s yang apabila mendapat awalan me-, maka akan menjadi nasal. Kata mensiasat pada kalimat di atas kurang tepat jika belum diikuti sufiks $-i$ sehingga menjadi menyiasati.

$m e+$ siasat $+i=$ menyiasati

Perbaikan dari kalimat di atas sebagai berikut:

Karena kita perlu menyiasati agar bisa mengetahui perkembanganperkembangan setiap zamannya.

\section{Kesalahan Penulisan Kata Depan}

Wujud kesalahan

a. Perkembangan hukum Islam telah terjadi sejak Rasulullah Saw lahir kedunia.

Analisis kesalahan

Bentuk kata depan, seperti di, ke, dan dari, ditulis terpisah dari kata yang mengikutinya. Penulisan kata depan ke- pada kata kedunia dalam kalimat tersebut kurang tepat. Sesuai dengan Pedoman Umum Bahasa 
Indonesia $(P U E B I)$, penulisan kata kedunia harusnya dipisah karena tidak menunjukkan kata tempat.

$k e+$ dunia $=$ ke dunia

Perbaikan dari kalimat di atas sebagai berikut:

Perkembangan hukum Islam telah terjadi sejak Rasulullah Saw. lahir ke dunia.

b. Ke dua adanya pengikut-pengikut yang menyebarluaskan.

Analisis Kesalahan

Bentuk kata depan ke- seharusnya tidak dipisah dengan kata dasarnya karena kata depan seperti $d i$, dan ke jika kata dasarnya tidak menunjukkan kata tempat.

$k e+d u a=k e d u a$

Perbaikan dari kalimat di atas sebagai berikut:

Kedua adanya pengikut-pengikut yang menyebarluaskan.

\section{Kesalahan Penulisan Simulfiks me-kan}

Wujud kesalahan

Faktor-faktor yang penyebab pertumbuhan hukum Islam.

Analisis terhadap kesalahan

Bentuk kata dasar yang berfonem awal $\mathrm{k}, \mathrm{p}, \mathrm{t}$, dan $\mathrm{s}$ akan luluh jika diikuti prefiks me-. Seperti kesalahan pada penulisan kata penyebab. Bentuk dasar kata sebab berfonem awal s dan apabila mendapat awalan me-, maka akan menjadi menyebab. Kata menyebab pada kalimat di atas kurang tepat jika tidak diikuti sufiks -kan sehingga menjadi menyebabkan.

$m e+s e b a b+k a n=$ menyebabkan

Perbaikan dari kalimat di atas sebagai berikut:

Faktor-faktor yang menyebabkan pertumbuhan hukum Islam.

\section{Kesalahan Pemakaian Konfiks ke-an}

Wujud kesalahan

Sehingga siapapun yang memiliki mampu berijtihad maka boleh melakukan ijtihad.

Analisis terhadap kesalahan 
Kata mampu pada kalimat di atas kurang tepat, karena kalimat menjadi tidak baku. Jika konfiks ke-an digabungkan dengan kata dasarnya, maka membentuk kata baru, sehingga menjadi kemampuan.

ke+mampu+an $=$ kemampuan

Perbaikan terhadap kalimat di atas sebagai berikut:

Sehingga siapapun yang memiliki kemampuan berijtihad, maka boleh melakukan ijtihad.

\section{Kesalahan Penulisan Konfiks per-an}

Wujud kesalahan

Sehingga setiap masalah yang muncul cukup dijawab dengan alquran dan sunnah serta sedikit fatwa para sahabat bagi masalah-masalah tertentu.

Analisis terhadap kesalahan

Bentuk konfiks per-an melekat dengan bentuk dasarnya. Konfiks per-an dapat membentuk kata baru ketika konfiks tersebut mengikuti bentuk dasarnya. Penggunaan konfiks per-an pada kalimat di atas membuat kalimat menjadi padu.

per + masalah + an $=$ permasalahan

Perbaikan terhadap kesalahan sebagai berikut:

Sehingga setiap permasalahan yang muncul cukup dijawab dengan alQur'an dan sunnah serta sedikit fatwa para sahabat bagi masalah-masalah tertentu.

\section{PEMBAHASAN}

Berdasarkan analisis kesalahan berbahasa dari data hasil penelitian yang sudah disampaikan sebelumnya. penelitian ini menunjukkan adanya berbagai kesalahan morfologi dalam makalah mahasiswa Hukum Ekonomi Syariah IAIN Surakarta dengan disertai analisis perbaikan data temuan kesalahan morfologi tersebut.

Berikut pembahasan berdasarkan analisis perbaikan data temuan kesalahan morfologi dalam makalah mahasiswa Hukum Ekonomi Syariah IAIN Surakarta.

\section{Kesalahan dalam Penulisan Prefiks di-}

Berdasarkan hasil dan analisis pada penelitian di atas, penulisan prefiks $d i$ yang seharusnya digabung tetapi dipisah ditemukan empat kesalahan dari dua puluh tiga makalah yang telah diteliti. Penulisan prefiks $d i$ - banyak yang mengalami kekeliruan yang seharusnya penulisannya digabung menjadi dipisah.

\section{Kesalahan dalam Penulisan Kata Depan di-}


Berdasarkan hasil dan analisis pada penelitian di atas, penulisan prefiks diyang seharusnya dipisah tetapi digabung ditemukan tiga kesalahan dari dua puluh tiga makalah yang telah diteliti. Penulisan prefiks $d i$ - banyak yang mengalami kekeliruan, yang seharusnya penulisannya dipisah menjadi digabung.

\section{Kesalahan Penulisan Prefiks ber-}

Berdasarkan data dan analisis dari penelitian di atas, kesalahan penulisan prefiks ber- hanya memiliki satu kesalahan dari dua puluh tiga makalah yang diteliti.

\section{Kesalahan Penulisan Prefiks me-}

Berdasarkan data dan analisis dari penelitian di atas, kesalahan penulisan prefiks me- hanya memiliki satu kesalahan dari dua puluh tiga makalah yang diteliti.

\section{Kesalahan Penulisan Prefiks ter-}

Berdasarkan data dan analisis dari penelitian di atas, kesalahan penulisan prefiks ter- hanya memiliki satu kesalahan dari dua puluh tiga makalah yang diteliti.

\section{Kesalahan dalam Pemakaian Sufiks -nya}

Berdasarkan data dan analisis dari penelitian di atas, penulisan sufiks -nya memiliki dua kesalahan dari dua puluh tiga makalah yang diteliti

\section{Kesalahan dalam Pemakaian Sufiks -kan}

Berdasarkan data dan analisis dari penelitian di atas, penulisan sufiks - kan memiliki dua kesalahan dari dua puluh tiga makalah yang diteliti.

\section{Kesalahan Penulisan Gabungan Prefiks di- dengan Sufiks - kan}

Berdasarkan data dan analisis dari penelitian di atas, kesalahan penulisan prefiks $d i$ - dengan sufiks - kan hanya memiliki satu kesalahan dari dua puluh tiga makalah yang diteliti.

\section{Kesalahan Penulisan Gabungan dari Prefiks me- dengan Sufiks - $\boldsymbol{i}$}

Berdasarkan data dan analisis dari penelitian di atas, kesalahan penulisan prefiks $m e$ - dan sufiks $i$ hanya memiliki satu kesalahan dari dua puluh tiga makalah yang diteliti.

\section{Kesalahan Penulisan Kata Depan}

Berdasarkan data dan analisis dari penelitian di atas, kesalahan pada penggunaan kata depan memiliki dua kesalahan dari dua puluh tiga makalah yang diteliti.

\section{Kesalahan Penulisan Simulfiks me-kan}


Berdasarkan data dan analisis dari penelitian di atas, kesalahan penulisan simulfiks me-kan hanya memiliki satu kesalahan dari dua puluh tiga makalah yang diteliti.

\section{Kesalahan Pemakaian Konfiks ke-an}

Berdasarkan data dan analisis dari penelitian di atas, kesalahan penulisan konfiks ke-an hanya memiliki satu kesalahan dari dua puluh tiga makalah yang diteliti.

\section{Kesalahan Penulisan Konfiks per-an}

Berdasarkan data dan analisis dari penelitian di atas, kesalahan penulisan konfiks per-an hanya memiliki satu kesalahan dari dua puluh tiga makalah yang diteliti

\section{SIMPULAN}

Berdasarkan analisis kesalahan berbahasa pada bidang morfologi dalam makalah mahasiswa Hukum Ekonomi Syariah semester VI Institut Agama Islam Negeri Surakarta tahun 2019 telah ditemukan 13 kesalahan baik penggunaan prefiks, afiks, simulfiks, maupun konfiks. Namun, kesalahan terbanyak pada penulisan makalah mahasiswa Hukum Ekonomi Syariah yaitu pada penulisan prefiks di- yang memiliki kesalahan sebanyak tujuh sehingga hal tersebut mengindikasikan bahwa mahasiswa Hukum Ekonomi Syariah terkhusus pada kelas D angkatan tahun 2016 belum menguasai secara maksimal penulisan prefiks di- secara baik dan benar.

Selain itu, juga masih ditemukan kesalahan-kesalahan lain dalam penulisan. Pemilihan kata yang kurang tepat juga masih ditemui sehingga masih belum menerapkan penulisan dengan baik dan benar yang berpedoman pada Pedoman Umum Ejaan Berbahasa Indonesia (PUEBI). Hal tersebut membuat kalimat menjadi rancu yang menyebabkan makna menjadi kurang jelas. Berdasarkan hal tersebut maka penting bagi mahasiswa ataupun pelaku akademisi untuk senantiasa memahami kebahasaan yang baik dan benar tidak hanya dalam ranah lisan melainkan juga tulisan.

\section{DAFTAR PUSTAKA}

Arikunto, S. (2009). Manajemen Penelitian. Jakarta: Rineka Cipta.

Ariningsih, N. E., Sumarwati, \& Kundharu, S. (2012). Analisis Kesalahan Berbahasa Indonesia dalam Karangan Eksposisi Siswa Sekolah Menengah Atas. BASASTRA Jurnal Penelitian Bahasa, Sastra Indonesia dan Pengajarannya, $1(1)$.

Badudu, J. S. (1985). Pelik-Pelik Bahasa Indonesia. Bandung: Pustaka Prima. Dalman, H. (2014). Keterampilan Menulis. Jakarta: Raja Grafindo Persada.

Fajriyani, N., Ridho, M. R. \& Laili, Q. (2020). Analisis Kesalahan Berbahasa di Bidang Diksi dalam Buku Panduan UPT Perpustakaan IAIN Surakarta Edisi 2018. Jurnal Penelitian Humaniora 21(1),55-68. https://doi.org/10.23917/humaniora.v21i1.8151. 
Gie, T. L. (2002). Terampil Mengarang. Yogyakarta: Balai Pustaka.

Mahsun. (2005). Metode Penelitian Bahasa. Jakarta: PT Raja Grafindo Persada.

Markhamah, \& Sabardila, A. (2011). Analisis Kesalahan dan Karakteristik Bentuk Pasif. Surakarta: Jagat Abjad.

Nurgiyantoro, B. (2010). Penilaian Pembelajaran Bahasa. Yogyakarta: BPFE.

Nurwicaksono, B. D., \& Diah, A. (2018). Analisis Kesalahan Berbahasa Indonesia pada Teks Ilmiah Mahasiswa. AKSIS Jurnal Pendidikan Bahasa Dan Sastra Indonesia, 2.(2).hal: 138-153. DOI:https://doi.org/10.21009/AKSIS.020201.

Priyono, Y. (2012). Analisis Kesalahan Berbahasa Bidang Morfologi pada Mading di Universitas Muhammadiyah Surakarta. Skripsi. FKIP Universitas Muhammadiyah Surakarta. URI: http://eprint.ums.ac.id/id/eprint/21049.

Reistanti, A. P. (2017). Analisis Kesalahan Berbahasa pada Penulisan Cerita Fabel Oleh Siswa Kelas VIII E di SMP 2 Muhammadiyah Surakarta. Kajian Linguistik dan Sastra, 2(2) hal: 126-140. DOI: https://doi.org/10.23917/kls.v2i2.6735.

Rohmadi, Dkk. (2012). Morfologi: Telaah Morfem dan Kata. Surakarta: Yama Pustaka.

Santoso,T. \& Sabardila, A. (2018). Analisis Kesalahan Berbahasa Pidato Mahasiswa Magister Pengkajian Bahasa Universitas Muhammadiyah Surakarta yang Memerankan Diri Menjadi Calon Kepala Daerah Kabupaten Blora. Jurnal Penelitian Humaniora. 19 (2), 17-27. DOI: https://doi.org/10.23917/humaniora.v19i2.6043

Slavin, R. E. (2011). Cooperative Learning Teori, Riset dan Praktik. Bandung: Nusa Media.

Subroto, E. (1992). Pengantar Metode Penelitian Linguistik Struktural. Surakarta: UNS Pres.

Sudaryanto. (2015). Metode dan Aneka Teknik Analisis Bahasa. Yogyakarta: Duta Wacana University.

Sutrisna, D. (2017). Analisis Kesalahan Morfologi Bahasa Indonesia dalam Surat Kabar Radar Majalengka Edisi 16 dan 25 April 2016. Diglosia Jurnal Pendidikan, Kebahasaan, dan Kesusastraan Indonesia, 1(1), hal: 16-33. https://Jurnal.unma.ac.id

Tanjung, \& Ardial. (2010). Pedoman Menulis Karya Ilmiah (Proposal, Skripsi, dan Tesis). Jakarta: Kencana. 